\title{
CT findings in Fahr's disease
}

\author{
Shamsh Tabrez Alam, ${ }^{1}$ Yashant Aswani, ${ }^{2}$ Karan Manoj Anandpara, ${ }^{2}$ Priya Hira ${ }^{2}$
}

${ }^{1}$ Patna Medical College and Hospital, Patna, Bihar, India ${ }^{2}$ Seth G S Medical College and KEM Hospital, Mumbai, Maharashtra, India

Correspondence to Dr Yashant Aswani, aswaniyashant@gmail.com

Accepted 26 February 2015
CrossMark

To cite: Alam ST, Aswani Y, Anandpara KM, et al. BMJ Case Rep Published online: [please include Day Month Year] doi:10.1136/bcr-2014208812

\section{DESCRIPTION}

A 65-year-old man presented to our services with features of dementia and movement disorder for 2 years. The symptoms had worsened over the past month with development of auditory hallucinations. CT demonstrated extensive calcification in bilateral basal ganglia, grey-white matter junctions and dentate nuclei. Serum calcium, phosphate and parathormone levels were normal. Fahr's disease was diagnosed based on the clinical and imaging findings.

Fahr's disease is an autosomal dominant inherited disorder characterised by basal ganglia and extraganglionic calcification, extrapyramidal symptoms and psychosis. ${ }^{1}$ Usual age of presentation is
40-60 years with no gender predilection. ${ }^{1}$ Psychosis is proportionate to degree of calcification and cerebral atrophy. Calcification typically occurs in the lateral part of the globus pallidus, dentate nuclei and caudate nuclei. ${ }^{1}{ }^{2}$ Other sites include grey-white matter junction, white matter tracts and thalami (figure 1). However, the sites of calcification are not specific and a similar pattern may be found in hypoparathyroidism, pseudohypoparathyroidism and hyperparathyroidism. ${ }^{2}$ Normal calcium, phosphate and parathormone levels in Fahr's disease aid in diagnosis. ${ }^{12}$ Other differentials include senescent calcification (punctate, less extensive, occurring in the medial globus pallidus), HIV encephalopathy (cerebral
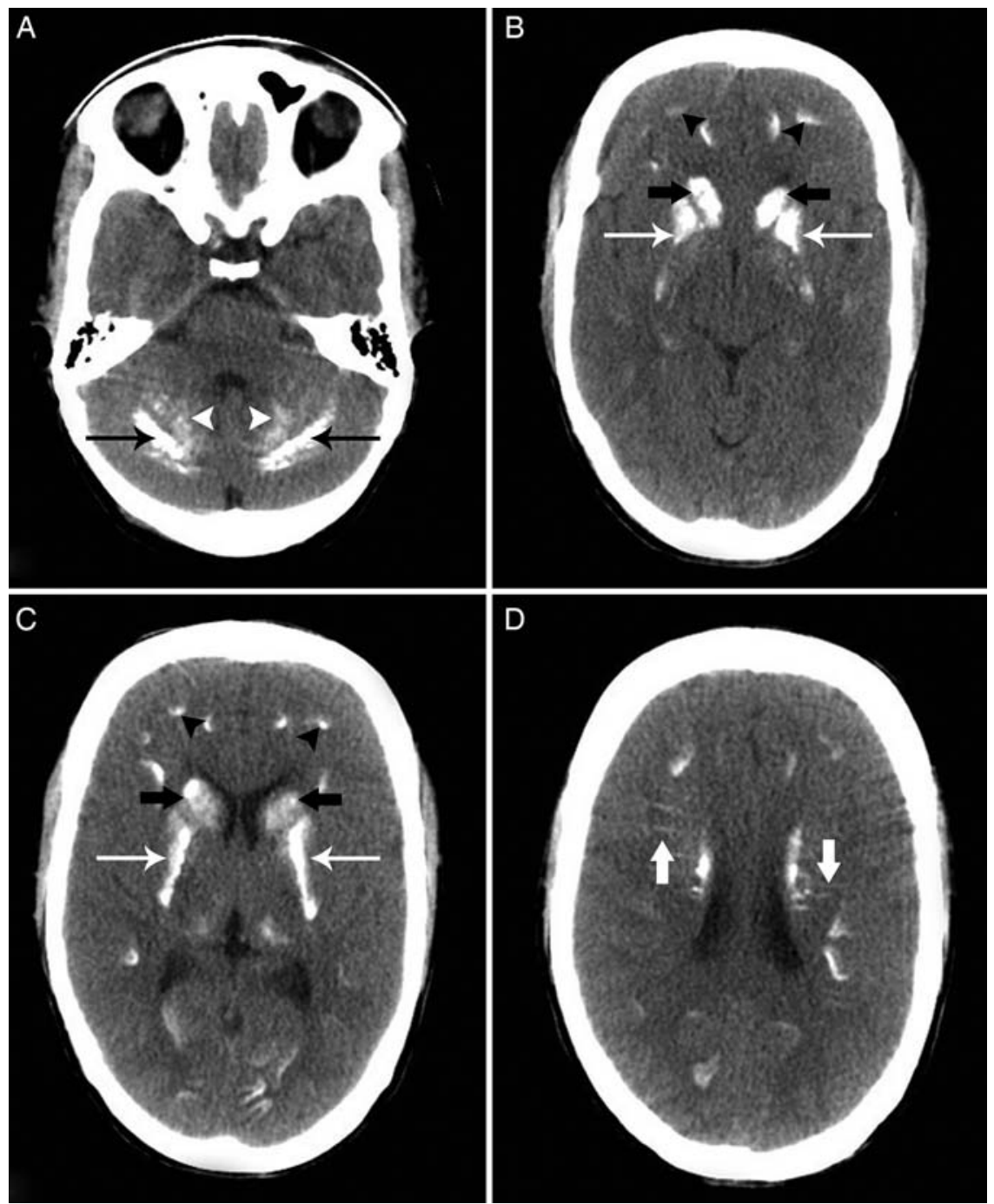

Figure 1 Fahr's disease (Striopallidodentate calcinosis). Axial non-contrast CT depicts bilateral symmetric calcifications in cerebellar foliae (thin black arrows) (A). Also note calcification in both dentate nuclei (white arrowheads) (A). There is extensive bilateral calcification in head of caudate nuclei (thick black arrows) (B and C), putamina and lateral globus pallidi (thin white arrows) with relative sparing of medial globus pallidi and thalami (B). There is calcification at grey-white matter junction as well (black arrowheads) (B). Linear calcification is seen to extend perpendicularly from the caudate nuclei (thick white arrows) (D). 


\section{Learning points}

Differentials for extensive calcification in basal ganglia, grey-white matter junction, dentate nuclei and thalami include Fahr's disease, hypoparathyroidism, pseudohypoparathyroidism and hyperparathyroidism. Other causes are senile calcification, calcification in HIV encephalopathy, Cockayne syndrome, and as sequelae to intrathecal chemotherapy and radiotherapy to brain.

- Fahr's disease also known as striopallidodentate calcinosis, typically exhibits calcification of basal ganglia and extraganglionic sites, Parkinsonian-like features and schizophrenia-like symptoms.

- There is no specific treatment for Fahr's disease. Antipsychotic medication has been tried but these patients are more prone to develop malignant neuroleptic syndrome with antipsychotic treatment. atrophy, low CD4 counts), Cockayne syndrome (dwarfism, microcephaly, mental retardation, cerebral atrophy), and as sequelae to intrathecal chemotherapy and radiotherapy to the skull. ${ }^{2}$

Non-contrast CT is the most sensitive modality and there is lack of enhancement in regions of calcification. ${ }^{2}$ Prognosis is poor since the disease is progressive and there is no specific treatment. Antipsychotics may be used; but patients with Fahr's disease are more susceptible to adverse effects such as malignant neuroleptic syndrome. ${ }^{3}$

Competing interests None.

Patient consent Obtained.

Provenance and peer review Not commissioned; externally peer reviewed.

\section{REFERENCES}

1 Acou M, Vanslembrouck J, Deblaere K, et al. Fahr disease. JBR-BTR 2008:91:19.

2 Hegde AN, Mohan S, Lath N, et al. Differential diagnosis for bilateral abnormalities of the basal ganglia and thalamus. Radiographics 2011;31:5-30.

3 Ghormode D, Maheshwari U, Kate N, et al. Fahr's disease and psychiatric syndromes: a case series. Ind Psychiatry J 2011;20:136-8.

Copyright 2015 BMJ Publishing Group. All rights reserved. For permission to reuse any of this content visit http://group.bmj.com/group/rights-licensing/permissions.

BMJ Case Report Fellows may re-use this article for personal use and teaching without any further permission.

Become a Fellow of BMJ Case Reports today and you can:

- Submit as many cases as you like

- Enjoy fast sympathetic peer review and rapid publication of accepted articles

- Access all the published articles

- Re-use any of the published material for personal use and teaching without further permission

For information on Institutional Fellowships contact consortiasales@bmjgroup.com

Visit casereports.bmj.com for more articles like this and to become a Fellow 